\title{
Men in Eugenic Times: Wallace Thurman's Infants of the Spring and the (Im)possibility of Cosmopolitan Friendship
}

In 1959, after being awarded the Lessing Prize of the Free City of Hamburg, in her acceptance speech Hannah Arendt dwelt with compelling force on the subject of friendship. She drew attention to the cosmopolitan dimension of the occasion and took the opportunity to elaborate on the strange trajectory of cosmopolitanism and transatlantic friendship; after all, the German city granted the award to a Jewish-German intellectual, who was then living permanently in the United States due to her escape from Nazi Germany twenty-six years earlier. For Arendt, friendship "seems pertinent to the question of humanness" (31) and is inextricably intertwined with the problem of worldliness, i.e. of people's relation to the material world. Friendship is a fundamental notion that builds human identity, as well as shapes the community and the world we live in. Arendt's musings provide the background to the problem that is addressed in this chapter: that of cosmopolitan friendship at times which are intrinsically inimical to it. I am interested in investigating how political and racial divisions, as well as the discourse of racial absolutism, which are prominent in certain epochs, affect the shape of interracial and cosmopolitan friendships. What is the relationship between oppressive and divisive politics and human interracial and cross-geographical intimate bonding?

While talking about friendship, Arendt makes a distinction between friendship that is realized through a commonality of suffering and that which is fulfilled through its participation in the world. The former is "a privilege of pariah peoples" (21) and constitutes "humanity in the form of fraternity" (20) among "the repressed and persecuted, the exploited and humiliated" (21). Fundamental as it is during times of persecution, and as rich and warm as it is, it comes at a dear price-erasure from the world. Thus those that bond in pariahdom pay with their "invisibility," which always means "a loss to the world" (21). An alternative friendship is one "in the world" and "of the world," even though it may be more difficult, or even impossible, to realize during times of persecution. To Arendt, this "worldly" cosmopolitan friendship across borders and ethnic and racial divisions, by engaging with difference allows people to truly participate in the world as "world citizens." It is also this type of friendship that can leave an indelible mark on the shape of the political world at large, change the world, and bring "a bit of humanness" to it (31).

Arendt's speculations are compatible with contemporary cosmopolitan theory. In its post-World War II and post-1960s reformulation, cosmopolitanism is perceived as a moral and political project "of productive global interdependence" aimed at furthering the ideal of "belonging to a harmonious global community of cosmopolitan 
citizens” (Braidotti 1). Cosmopolitanism, regardless of its conceptualization, be it the universalistic neo-Kantianism promoted by Jürgen Habermas and David Held, or that of a "nomadic 'becoming-world' or "cosmopolitanization from below" as advocated by Braidotti and Hall respectively (Braidotti 2; Werbner 346), is aimed at furthering people's status as "world citizens," which would bring them into a free interaction with the world in order to construct it together. The cosmopolitan project concerns the whole of humanity and thus is "pan-human" (Braidotti 3), and engages both those that are free to experience the world due to their racial, ethnic, national or economic privilege, and in an equal degree those that are reduced to the status of political pariahs: individuals suffering ethnic, racial, sexual or religious persecution, economic and illegal immigrants, and political refugees. Focusing on human interactions and "attentive to the material reality of our social and political situation" (Braidotti 3), the new cosmopolitanism is interested in both global friendship as well as its place in the material world, and so explores what Arendt labels as people's worldliness and humanness. Arendt's speculations may enrich our understanding of the conditions necessary for cosmopolitan friendship to exist in the world, and thus to be "of the world." Her distinction between the friendship in oppression (which Arendt identifies with "brotherhood"), realized through an escape from a hostile world; and friendship realized "in the world" and claiming the right to engage with it, enables a nuanced approach to the discussion of friendship in different and difficult political contexts. It may shed additional light on the question of the possibility of cosmopolitan "worldly" friendship in a world that objects to it on principle, and thus forces people to withdraw into the fraternité of pariahdom. Moreover, it may facilitate an understanding of the trajectory of friendship at a time that privileges human bonding in "biology" and contests bonding in "culture," as was the case during Arendt's forced escape from Germany in 1940. Arendt's philosophy provides us with an interesting perspective to the following tormenting questions: Can cosmopolitan friendship grow and offer a challenge to the political division of individuals into world citizens and world pariahs? Can it flourish during times of oppressive politics and mendacity, the dubious ethics of which was captured by Arendt in the term "false politics"? Or, to put it simply, is cosmopolitan friendship possible in what Arendt labeled as "Dark Times"?

As Arendt demonstrates, nowhere was the question of the relationship between cosmopolitan friendship and "false politics" more pertinent than at the times of the triumph of eugenics in the Western world on the eve of World War II. The eugenic discourse of nativism and racial absolutism (Gilroy, Against Race 285), which valorized family and racial purity, had little patience with friendships forged above familial relationships (Michaels 40-52). Bonding across racial lines was an anathema to the eugenic language of biological typology, which stressed the role of heredity in civilization. It is interesting to observe how the United States, which traditionally has prided itself on the uniqueness of its civic state democracy and its myth of US exceptionalism, has responded to the eugenically-induced debates around two different models of culture: one based on tribal affiliations, and the other on friendship. Being the 
pulse of the time, US literature before World War II dutifully mirrored the two dominant strands in the then-contemporary thinking. It either endorsed the discourse of nativism and family and neglected that of friendship-thus leading to the emergence of "nativist modernism" (Michaels 6-17)-or it challenged the primacy of the family and developed a fascination with the figure of a nomadic orphan-"extraterritorial" and in search of friends-and as Edward Said argues, one of the major tropes of modernism (138). Among the novels that addressed the question of cosmopolitan friendship in times dominated by a eugenic discourse, Infants of the Spring (1931), by African American writer Wallace Thurman, stands out. The book offers a vivid and disturbing portrayal of the rise and fall of interracial and transatlantic friendship in the 1920s Harlem in New York-probably one of the most cosmopolitan cities of the decade. The daring cosmopolitan friendship described in the book refuted the eugenic advocacy of racial purity and challenged the rhetoric of racial segregation disseminated in accord with the theory of social Darwinism and legally enacted in the US South, but over time it met with a sad end. The termination of an intimate relationship between two "strangers" invites one to look into the reasons for the failure and thus raises the question of the conditions necessary for a cosmopolitan friendship to exist during times dominated by "false politics."

The discussions of Wallace Thurman's Infants of the Spring are generally overshadowed by critical analysis of The Blacker the Berry-the first novel authored by Wallace during a promising writing career that ended with his untimely death at the young age of 32. If The Blacker the Berry is praised for its masterful depiction of the problem of colorism and racism in the life of a young black woman in the 1920s (Rottenberg), and for thus enacting Thurman's belief “that fiction writers were obliged to reach beyond the boundaries of their own personal lives" (Ganter 88), Infants of the Spring confuses readers and critics with its language of Mencken-inspired individualism, which assumes a radical "terminal" shape that "stands in stark opposition to group membership" (Singh 11) as well as breeds "corrosive contempt” (Posnock 82). Most likely discouraged by the novel's harsh critique of the Harlem Renaissance, which was identified with the discourse of racial uplift, the critics frequently bypass the novel's much larger political and social contexts and consequently, its radical refutation of the discourse of racial absolutism and its concomitant cosmopolitanism. When interpreting the novel, they tend to look at the intimate and the personal and focus on the novel's treatment of sexuality and queerness-which is also a logical direction to take given the novel's desire to shatter up the bourgeois code of respectability of the 1920s and Thurman's experimentation with his own sexuality (Ganter; Knadler; Pochmara 125-135, 141-177). I argue, however, that placing the novel against the social and scientific disputes of the time, and especially within the framework of eugenics, allows the reader to see the novel's sometimes confusing political and artistic choices in a new light. Juxtaposing the novel against the science of eugenics, perceived in the 1920s to be one of most vibrant and visionary sciences, facilitates a 
grasp of what I perceive to be one of the novel's central preoccupations: the question of interracial, inter-cultural and transatlantic cosmopolitan friendship.

Both the figure of friendship and the discourse of eugenics are introduced into the novel right at the beginning, thus setting the tone for the whole work. When welcoming Steven, a new student at Columbia, to his studio in Harlem in the company of Samuel, Raymond, the black painter, engages in a monologue that is a display of wit, brilliance and irony:

\begin{abstract}
"Sam doesn't like my studio, though he thinks it's decadent. ... Namely, the red and black draperies, the red and black bed cover, the crimson wicker chairs the riotous hook rugs, and Paul's erotic drawings, You see, Steve, Sam thinks it's all rather flamboyant and vulgar. He can't forget that he's a Nordic and that I'm a Negro, and according to all the sociology books, my taste is naturally crass and vulgar. I must not go in for loud colors. It's a confession of my inferior race heritage. Am I right, Sam?"

"It’s all Greek to me anyhow,” Stephen murmured. (3)
\end{abstract}

Raymond's opening monologue, interspersed with remarks by Samuel and Steven, prepares the reader for what is about to come. The three young men, while eager to pursue their friendship, are divided by different attitudes towards the discourse of degeneracy, widespread in the United States in the 1920s. If Steven has no insight into the content of the conversation, both Raymond and Samuel exhibit an excellent command of the topic. Samuel, a white social reformer who has dedicated his life to the cause of racial equality, worries that the studio's bright colors and its parading of erotic paintings may testify to Raymond's "inferior race heritage" and debunk "the ideal of bourgeois acceptability endemic to programs of 'racial uplift" " (Pinkerton 539). On the other hand Raymond, a black artist seeking inspiration and artistic energy in Harlem, chooses to ridicule the language of racial decadence. Thus, while Samuel's world is overshadowed by a fear of the black man sliding into degeneration and never "develop[ing] the strength to climb" (Roosevelt 9) the social and evolutionary ladder-an anxiety shared by such politicians as President Theodore Roosevelt-Raymond dismisses those fears as totally ungrounded. Even though both of them, as Americans and friends, are divided on the issue of degeneracy, they display a similarly thorough knowledge of the language of eugenics that mixed an older language of degeneracy with the agenda of social Darwinism. Whereas earlier theories of degeneracy tended to focus on the manifestation of decadence across classes-by warning against degeneration in art (Nordau) or developing the theory of the "criminal man" (Lombroso)-the language of evolution and social Darwinism gave those speculations a racial bias well-suited to the North American climate of racialism and racism. ${ }^{35}$ Samuel and Raymond seem familiar with the conceptual rhetoric of racial

35 On the discussion of degeneracy in US literature in the first two decades of the twentieth century and especially in the fiction of Jack London, see Luczak (67-97). 
degeneracy popularized by top US eugenicists of the time-David Star Jordan, Albert Ross, Madison Grant, and Lothrop Stoddard-a rhetoric that was both contested and partially incorporated by such progressive intellectuals as Clarence Darrow and H.L. Mencken respectively, who had little patience with "the eugenics cult." ${ }^{36}$ Samuel and Raymond's awareness of the rhetoric of racial degeneracy is not unique, but rather a token of the times. The list of US intellectuals and writers impacted by the science of eugenics includes Jack London, Charlotte Perkins Gilman, Willa Cather, T.S. Eliot, Gertrude Stein, F. Scott Fitzgerald, William Faulkner, Ernest Hemingway, Sinclair Lewis and, in the context of the Harlem Renaissance so much closer to Thurman's home, George Schuyler and Nella Larsen (Currell and Codgell; Childs; English; Luczak; Nies; Schalk). For the two friends from Thurman's novel, raised and educated in the United States, the language of eugenics not only provides the background for their discussions but is also responsible for shaping truth claims about their environment. It is what they fall back upon when they refer to the world. Their world, or what Arendt would call the worldliness-relationship forged with people in the world and with the world itself-cannot exist without eugenic assumptions about the evolutionary nature of human races. Consequently, the friendship between Samuel and Raymond is always enacted in the space charted by eugenics.

The case of Steven and his relationship to Samuel and Raymond is radically different. When the young New Yorkers disagree about the decadent nature of Raymond's studio, Steven pronounces somewhat naively and self-righteously, most likely to avoid being drawn into the discussion, that "it's all Greek to me" (3). Steven is a foreigner, a new student at Columbia University who has just arrived from Toronto to the cosmopolitan New York, throbbing with Jazz music and the spirit of Freudianism. His status as an outsider is further emphasized by the fact that he is originally from Denmark, with his father being Norwegian and his family still living on the old continent. Naturally, his otherness places him at a disadvantage in the new environment due to his inability to interpret US cultural codes, one of them being the discourse of eugenics. Eugenics, known as the science of heredity, was by no means a US invention: as a matter of fact it originated in and was spread from the UK and soon became a cutting-edge science of the entire Western world, including Denmark and Canada (Turda; Turda and Weindling; Weiss-Wendt and Yeomans). Yet the popularity it reached in scientific circles and its status as a popular discourse in the UK, Germany

36 "In the last ten years the reading public has been bombarded by books and articles on eugenics. In the main these articles set forth a single thesis: that doom hangs over the human race. Of course, we have all known for a long time that each individual of the human race is doomed. Though we seldom speak of it and try not to think of it, every man inevitably comes to the realization that in time his own life must pass. The eugenicists' concern, however, is not over the fact that we die one by one. What alarms them is that the race is apparently bent upon committing a wholesale biological harikari" (Darrow 129). Mencken both criticized eugenics and endorsed it with respect to poor white trash in the US South in Asepsis and "Sahara of the Bozart" respectively. 
and the United States were unprecedented (Cuddy; Kline; Kuhl; Luczak; Stern) and may account for Steven's avoidance of the topic. Thus Steven follows neither Raymond's inquisitions on Nordicism nor Samuel's tirades on racial responsibility. His lack of cultural awareness, however, places him in favor with Raymond, who seizes the opportunity to establish a rapport free of racial bias. Raymond notes with satisfaction how Steven "[s] urprisingly enough ... [is] foreign, foreign to everything familiar either to Samuel and myself" (5) and plunges into a friendship with the young Dane.

Unencumbered and uncorrupted by mutual resentments, prejudices and theories of racial supremacy, the friendship between the two men develops at a fast pace. Its rapid flowering and "virginal” (Van Notten 272) quality invoke relationships developed by innocent children in their reception of each other and the world. Already on the first day of their meeting Raymond enthusiastically exclaims, "Steve, I feel as if I had known you all my life" (5), and after a week invites the man to share his apartment. In turn, when Steven is confronted with criticism from Samuel for his involvement in the black community of Harlem, he cheekily proclaims to Raymond: "You're the only friend I give a damn about" (4). The friendship of the young men seems to be unconditional and oblivious to the restrictions of the outside world:

Stephen had been in New York for a month now, and most of that month had been spent in the company with Raymond. Their friendship had become something precious, inviolate and genuine. They had become as intimate in that short period as if they had known on each other since childhood. In fact, there was something delightfully naïve and childlike about their frankly acknowledged affection for one another. Like children, they seemed to be totally unconscious of their racial difference. (17)

The physical and emotional proximity between the two men when they spend "most of [the] month in each other's company," is further sealed by their sharing of friends, be they female or male, and by their, even though only hinted at, mutual sexual attraction. It is assumed that the description of the intensity of the novel's friendship owes much to Thurman's personal experience of an intimate friendship with Harald Jan Stefansson-a Danish-Canadian introduced to Thurman by his friend Leland Petit (Van Notten 262). Described by Van Notten as Thurman's “most enduring love affair” (237) despite Stefansson's alleged heterosexuality (Van Notten 262), Thurman's relationship with the Danish-Canadian seems to have had a serious impact on the young African American writer at the time of his stay in Harlem.

Interestingly, Steve and Ray's desire for an ideal friendship based on radical proximity and blurring of borders between the selves is evocative of Giorgio Agamben's formula of friendship. According to Agamben, friendship is characterized by a radical proximity, whereby one's selfhood is re-inscribed and re-defined. Thus to him, the friend is "another self, a hetros autos," however he/she "is not another I, but an otherness immanent in self-ness, a becoming other of the self" " (6). Raymond and Steve's relationship of a childlike opening to the other seems to lead them to become hetros autos to each other. Generous in their welcome, "unmolested by the world and their 
demands" (Arendt 33) they invite the other to partake of their subjectivity and thus to shape their own self. Like in Agamben's musings, to them "friendship is ... de-subjectivization at the very heart of the most intimate perception of the self" (7).

What is interesting is that rather than being based on an intuitive understanding, the friendship between Steven and Raymond is rooted in conversations and grows through constant dialogues. And even though one can view the privileging of the intellectual bonding between the two men as a possible smoke screen for their passion, ${ }^{37}$ the stress the novel puts on their verbal exchanges deserves attention. The novel's omniscient narrator, who at times assumes the voice of the men's dual consciousness, notes how "[t]heir greatest joy came when they could be alone and talk, ... talk about any and everything" (17). Furthermore, he/she asserts that "[t]hey seemed to have so much to say to one another, so much that remained unsaid all of their respective lives because they had never met anyone else with whom they could converse unreservedly" (17). The linguistic nature of the rapport between Steven and Raymond allows them to discuss and ameliorate their differences and to grow in their conceptual world in a process not unlike that of a hermeneutic cycle. Engaging in long discussions in Raymond's studio in Harlem, Steven and Raymond resemble ancient philosophers from Aristotle's Nicomachean Ethics "living together, conversing and sharing (koinonein) their talk and thoughts” (Agamben 7). And just like in Ancient Greece, their friendship grounded in language is not a project that terminates upon reaching the solution to a philosophical problem, but a dialogue that opens new interpretations and horizons in the process of a conversation.

The parallel and comparison of Steven and Raymond's friendship and growth as intellectuals/philosophers with that of early philosophers is not as far-fetched as it seems. After all, as Agamben reminds us the beginnings of philosophy are linked to the notion of friendship and "the intimacy of friendship and philosophy is so deep that philosophy includes the philos, the friend, in its very name" (2). To Steven and Raymond, friendship nurtures their life philosophy and this philosophy helps them grow in friendship. The relationship between the two is circular, and one is not given priority over the other. Friendship and philosophy coexist on the same plane and need each other to sustain and prolong their existence.

The philosophy which the two men seem to construct together in the process of their unending conversations is a mixture of Nietzschean individualism and what initially looks like anti-foundationalism. Nietzscheanism is probably most conspicuous in the novel and testifies to Thurman's fascination with the thought of H. L. Mencken. In the 1910s and 1920s Mencken was a major US propagator of Nietzsche's philosophy, through The Philosophy of Friedrich Nietzsche $(1908,1913)$ and through his invention of a critical iconoclastic idiom that bespoke a strong, independent artis-

37 Van Notten notes how "suggestion of a sexual attraction between the two men is quickly dispelled" (272). 
tic will-de riguer with US intellectuals (Pochmara 139-140; Rampersad; Scruggs; Van Notten 108). Mencken's name is mentioned in Thurman's novel only once; after their break up, Ray teases Steve to sell the story about his experience to Mencken since "[h] e's so damned interested in Aframerican recently" (133). Yet, even if Mencken's name is not introduced in other contexts, and when referred to alludes only to his interest in and impact on African American intellectual life (Scruggs), his thought is present in the novel. This is in keeping with Thurman's own admiration for Mencken, the reading of whom, according to the writer, "generated the essential sparks needed to set my own mind and spirit on fire” (qtd. in Van Notten 109). In the novel, Mencken's spirit is etched onto Raymond's artistic pose of self-aggrandizement and "warfare against genteel Negro culture” (Scruggs 133), and frames his tirades against US society and the language of social duty and moral responsibility (Pochmara 139-140). When confronted with Sam's disapproval of his refusal to participate in the protests set up by the Brotherhood of Sleeping Porters, Ray retorts: "I'll be damned if I'll join in any crusade to save the Negro masses. I'm only interested in individuals" (42), thus invoking Mencken's ethos of extreme political individualism in conflict with the parochial Christian society. In a similar manner, when Raymond muses that despite "his superiority complex he was different from most people he knew, precociously different" and expresses his desire "to pervert rather that to train and cultivate this difference," he echoes Mencken's Nietzsche-inspired celebration of one's intellectual loneliness and the superiority of the Artist-Iconoclast. Likewise, Mencken's individualism is adopted by Steven, who staunchly defends his right to nonconformist choices, even if they fly in the face of social expectations and norms. When Samuel reprimands him for seeking assimilation with black people, and bitterly remarks: "You're quoting Ray now," Steven simply retorts: "I couldn't quote a more sane person" (4) and thus voices his allegiance to Raymond's philosophical choices.

The endorsement of Mencken's interpretation of Nietzscheanism-reinforced by what sounds like a diluted Guurdjieff's rhetoric, to which Thurman was introduced by Toomer (Singh 10)-leads both men to the radical rejection of the notion of race, a curious maneuver given Nietzsche's own racialized language. To the protagonists of Thurman's fiction, the philosophy of extreme elitist individualism with its rhetoric of artistic and intellectual superiority over a society burdened with its system of classification, rendered the language of races and racial typology obsolete. Thus, both men voice their dissatisfaction with racialism, grounded in what Naomi Popple calls "pigmentocracy," i.e. attribution of and valorization of certain attributes to people on the basis of the color of their skin. Raymond straightforwardly proclaims: "We want to lose our racial identity as such and be acclaimed for our achievements, if any" (124), whereas Steve thunders: "I like Ray, I like his friends, I like Aline ... and none of my likes are based on color. I know nothing about your damn American prejudices, except what I've read in books and been told. A person is a person to me" (28). I agree with Amritjit Singh when he points out that such a radical questioning of the validity of race to describe personhood and inter-personal relations is a sign of the book's 
perspicacity. It presages W.E.B. Du Bois's, Langston Hughes's and Richard Wright's exhaustion with racial essentialism, as well as anticipates the Critical Race Theory and the now commonly-shared belief that "race" is a social and legal construction (Singh 12).

Even though Steve's rejection of race invokes the Enlightenment imperative of fraternité, or of the much more current at the time Socialist language of equality, with which Thurman was familiar due to his work at The Messenger (Van Notten 105-108), both men are wary of any foundational philosophy that seeks essences and solid premises to explain the world. Steve's avid reaction to Sam's use of the slogans "All humans are equal" is a case in point. Sam is a man of big words, the purpose of which is to order the world and assure him of the inherent rightness of his actions. Used to "justify actions beliefs and lives," his words invoke Richard Rorty's "final vocabulary" which has the power to construct one's world and beyond which "there is only hopeless passivity or a resort to force" (Rorty 73). Dissatisfied with the final vocabulary, the core of a foundational philosophy intent on laying down philosophical foundations and exploring life's essences, Raymond and Steven seem eager to adopt a position that is close to Rorty's ironist. In Rorty's pragmatic philosophy of the 1980s, at odds with "final vocabularies" and meta-narratives, the ironist is an intellectual perfectly suited for the post-World War II world of scientific and religious uncertainty and contested claims of truth. The ironist is skeptical about world's discourses and has "radical doubts about the final vocabulary he currently uses, because he has been impressed by other vocabularies" (73). Such seems to be the case with Steven and Raymond in Thurman's novel. Flippant about themselves and others, cynical in their relationship with the world, and relying on irony and sarcasm in their dealings with people, the friends at first appear to adopt Rorty's style of an ironist. They are on guard against big credos and their skepticism targets the major social discourses of the time: that of social Darwinism, Marxism and eugenics. Their contestation of final vocabularies suggests their affinity with political pragmatism, attuned to "specificity rather than generality" (Braidotti, After Cosmopolitanism 3)-the backbone of contemporary cosmopolitan theory. They promise to form the philosophical basis for an effective opposition to the meta-narratives of the time, and thus provide the groundwork for a long-lasting cosmopolitan friendship.

However, there are two cracks in their adopted position of an ironist. Steve and Raymond desire to reject the world and turn their rejection of the world in the name of individualism and art into another foundational principle not unlike the dogmas they contest. Both their withdrawal from the world and their arrogant belief in the supremacy of their inner truths are in fact antithetical to Rorty's pragmatism, which is grounded in the world and celebrates those who "[do] not think [their] vocabulary is closer to reality than others" (73). Thus, both men act as limited ironists, who stop half way on their way to constructing a life philosophy and friendship that would pose an alternative to the essentialist language of racial eugenics and racial segregation. 
The same obstacles on the way toward reaching the pragmatic position of an ironist are responsible for the eventual failure of Steve and Raymond's friendship. As it turns out, when constructed on their withdrawal from the world and a belief in their impermeability to meta-narratives, their relationship does not withstand the test of time. When the men celebrate their inner world as an alternative to the strictures of society, the outside world intervenes and challenges their life philosophy and friendship. The belief in the possibility of creating a niche that would shelter one from the world may be appealing, but it is burdened with utopian impracticability. As the novel demonstrates, the world always strikes back, either through actions or through its language.

In this context, the house where both men share the apartment, which is modeled on the house Thurman lived in Harlem in the years 1926-1928, (Van Notten 169-211), takes on an interesting metaphorical meaning. Flippantly described as "Niggerati manor," a provocation thrown at both black bourgeois, genteel culture, and white supremacists alike, the house serves as an arena for much of the novel's action and is a symbol of the men's isolation from the world. And even though initially free of racialism and social censorship, the house turns out to be not immune to the codes and strictures of society. The first sign of the men's unwitting response to the social world is their compulsive search for heterosexual relations, as if to quench their anxiety over the possibly erotic nature of their intimacy and thus to meet heterosexual normativity (Pochmara 161-170). The ambiguity with respect to the women in the house may be a sign of the men's giving in to the demands of society, yet not in full accordance with their desires. The women they bond with do not live in the house but just come to visit, and thus remain outsiders. Whenever they come, they bring with them not only excitation but also, more significantly, a sense of destruction which suggests that their presence, associated with heterosexual normativity, forms a fissure in the ideal image of Steve and Ray's friendship.

Another way the outside world manifests its presence in the house is through its power to racialize human relations. Having internalized the US logic of white supremacy, two black women, Aline and Janet, compete for Steven, attracted to his "Nordic" looks. Their obsessive craving ends not only their friendship (when Steven chooses one of them), but also casts a shadow on the house's supposed a-racialism, since the woman chosen by Steven is of a light skin color. Moreover, when one of the house's black inhabitants, Pelham, gets arrested for rape, the white system of law interferes and violates the house's equanimity. Pelham ends up in jail, where his skin color puts him at a disadvantage and brings his friends face to face with legal racism. Additionally, police officers throw the community off balance by their brutal arrest of Pelham and aggressive interrogation of Steven and his girl-friend. Having been found in a house in Harlem inhabited by black people, Steven is treated with contempt for becoming "white trash" and Aline, suspected of passing for a white, is treated with the hatred accorded to those that challenge "the color line." Therefore, even though promising an escape from the brutal and racist environment and an asylum for inter- 
racial relations, the house, over time, becomes a signifier of Raymond's and Steven's growing disillusionment with their philosophical aspirations. It stands for the failure of their project of escape from the world, an escape that was grounded on the fallacy of the men's moral, artistic and apolitical strength. The change in the house's atmosphere attests to the tenuous nature of the hopes clustered around it. From a place vibrant with ideas and aspiring to be a hub of the Harlem Renaissance creativity, it turns into a speakeasy that breeds alcoholic lethargy. Its utopian nature is captured by a farewell drawing of Paul Arbian, drawn shortly before his suicide: it depicts the Niggerati Manor "on which were focused an array of blindingly white beams of flight" suspended in the air since "[t]he foundation of this building was composed of crumbling stone” (174). The picture's symbolic dimension is more than obvious: the idea of a world-free shelter endorsed by Raymond, Steven, and their friends is not grounded in material reality, and thus is bound to crumble any minute.

It turns out that Steve and Ray's trust in the possibility of shutting oneself from the world and forming a community of artists-philosophers immune to the material world is essentially flawed. In its utopianism it invokes romantic longings for places untouched by civilization and modernity, as manifested in Rousseau's philosophical project and evocative of US tradition of forming isolated communities such as the Brook Farm (1841-1847) or Fruitlands (1843-1844). In Thurman's novel, there is no escape from the outside world. Not only does the eugenic world react with violent actions, but both friends themselves bring the world they contest into their lives. Their "contamination" with the world and the impossibility of isolating oneself from it is also manifested in their language. The physical withdrawal from the world does not guarantee the disappearance of the sway the world holds over their language, and consequently over their minds and bodies. The world continues to control their language, and through it polices their bodies and shapes the ways they think about them.

And so, although devoid of explicit references to eugenics, Raymond's idiom is replete with phrasings and metaphors adopted from eugenic discourses, and these are not just instances of his jocular reference to the rhetoric of degeneracy. Eugenic phraseology, for example, is used when Raymond thinks, not without Nietzschean scorn, of how "the average Negro intellectual and artist had no goal, no standards, no elasticity, no pregnant germ plasm" (89-90; emphasis added) thus invoking the term used by eugenicists to describe the substance transmitting racial characteristics. Furthermore, eugenic rhetoric, widespread in the 1920s, of the threat posed by immigrants from Central and Southern Europe to the North American fabric, shapes Raymond's anxiety when visiting Pelham in jail. Having been placed in a waiting room "between the Irish mother of an incriminate policeman, and the Jewish sweetheart of an Italian gangster" Raymond cannot but be scared of the "strange accents and unfamiliar snatches of foreign dialects" and thus "want[s] to flee immediately" (126).

However, it is when Raymond muses on Steven's looks that his appropriation of the discourse of eugenics is most explicit. When seeing the new immigrant from Canada for the first time and comparing him to Samuel, Raymond relies on the lan- 
guage of Nordicism-a darling term in the science of heredity and the language of hip white intellectuals of the time (Luczak 164-169) - a fact recorded by Du Bois when he warns against "the cult of the Nordic totem" ("Americanization" 154):

Raymond once more went into the alcove to refill the empty glasses, his mind busy contrasting the two Nordics who were his guests, Stephen was tall and fashioned like a Viking. His hair, eyes and complexion all testified to his Norse ancestry. Samuel was small, pale, anemic, His hair was blond and his eyes were blue, but neither the blondness nor the blueness was as clearly defined or as positive as Stephen's. Samuel's ancestors had been dipped in the American melting pot, and as a result, the last of the line bore only a faint resemblance to his original progenitor. (Thurman 7)

When referring to the two white men as 'Nordics' and comparing Stephen to a Viking, Raymond relies on the racial typology of the time-a glaring inconsistency in light of his avowed rejection of racialism. Moreover, the juxtaposition of Samuel's short size and what is described as his "anemic looks" with Steven's imposing physique invokes the discourse of hybridity and smacks of the fear of miscegenation incited by eugenic leaders such as Charles Davenport and eugenic populists such as Lothrop Stoddard and Albert Wiggam. Wiggam was especially vocal about his belief in pernicious results of race mixing. His commitment to racial purity led him to celebrate the beauty of Lincoln-the President considered by Wiggam to be of pure Anglo-Saxon blood (Wiggam 277-8). Similarly, in Thurman's description of Steven, the purity of his Scandinavian ancestry translates into male virility and a proportionate body. By the way of contrast, Samuel's body is nothing but average-the effect of racial mixing of European immigrants in the US "melting pot."

Similarly, Steven echoes racial classifications of the time when he thinks of Raymond-a surprising fact in light of Steve's self-declared ignorance of US raciology. However, if to Raymond the racial mixing visible in Samuel's looks is a sign of racial decadence, to Steven the hybridity etched onto Ray's body promises a higher development and a new potential:

Stephen's keen, blue eyes more regarded the small slender Negro who sat opposite him, noting the smooth dark skin to which the amber colored bulbs imparted red overtones, and becoming particularly interested in racial features. They were, Stephen thought, neither Nordic nor Negroid, but rather a happy combination of the two, retaining slender outlines of the first, and the 'warm vigor' of the second, thus escaping both Nordic rigidity, and African coarseness. (6)

The inconsistency in the appraisal of the results of racial mixing in the two quotes signifies the whole range of attitudes among white and African Americans. On one hand, there were those who endorsed the racial segregation endemic to racial essentialism and entered such radically different political organizations as Marcus Garvey's UNIA or the white supremacist KKK. On the other hand were those who not only lashed racist's purists-like Du Bois in his essay provocatively titled "Miscegenation"-but even celebrated racial mixing, with George Schuyler's attempts to turn his mixed-race 
daughter into a perfect hybrid woman probably being the most notorious example (Talalay). The novel's confusion with respect to racial mixing appears to reflect the uncertainty of the writer himself, who does not know which attitude to take. Despite his tirades against race both in the novel, in other literary works, and in his private life (Van Notten 90), Thurman cannot free himself of the specter of race and the language of racial eugenics. Steven's blatant question to Raymond "aren't you hindered by some racial complex?" (33), and Raymond's brooding that his "struggle to free himself from race consciousness had been hailed before actually accomplished” (147) may provide a fitting commentary on Thurman's own position.

The writer's ambivalence with respect to the rhetoric of racial eugenics, however, may be understood when one bears in mind his experience as a pre-medical student at the University of Utah from January to June 1920 (Van Notten 85, Singh xvii). Eugenics, defined as a science of human improvement and better reproductive choices, significantly shaped the medical discourse of the time. The manuals in biology, anthropology and psychology-the syllabi for pre-medical students-had compulsory sections on races and the science of heredity. This was nothing unusual, given that even the manual in biology that challenged the ban on the teaching of the theory of evolution in Tennessee in 1925 included sections on eugenics and discussed eugenic "methods of improving the human race" (Hunter 373). The metaphors medical students lived by were to a large extent indebted to eugenics, and most likely assimilated by Thurman.

At this point one also has to keep in mind that eugenics had the ability to disguise itself as progressive discourse in the pre-World War II period, especially when it emphasized its positive aspect: a desire to promote the breeding of future race leaders. As such it appealed to socially-minded intellectuals focusing on racial uplift. The ranks of those who voiced interest in eugenics included W.E.B. Du Bois and Nella Larsen (English 117-140; Luczak 190-193; Schalk 148-150). English's book on eugenics and modernity and my own discussion of the involvement, even if limited, of black intellectuals in the early discourse of positive eugenics brings to mind the peculiar marriage between eugenic ideas and black reform. Not only did eugenics have the ability to structure the ways of thinking about racial uplift, but also to overshadow important artistic debates. The well-known exchange of essays between George Schuyler and Langston Hughes in the black press of the 1920s is a case in point. Whereas Schuyler hurriedly and arrogantly reduced the phenomenon of the New Negro Renaissance to the reiteration of the ideas of racial segregation in culture (the mantra of eugenicists such as Madison Grant and Lothrop Stoddard), Hughes staunchly defended the distinct nature of the African American race and culture, thus unwittingly echoing the widespread language of racialism.

If the omnipresence of eugenic discourse rendered liberation from it virtually impossible, then Thurman as well as his fictional characters construct their life philosophy on false premises. They trust the myth of the inner world, envisioned as a buffer and antidote to the oppressive reality and its language. However, their escape from the world is not only unfeasible, but also forces them into positions where they 
cannot cultivate their cosmopolitan friendships. Just like in Arendt's philosophy, the only friendship that can develop in the conditions of escape from the world is the friendship among pariahs, based on the commonality of oppression and suffering. Naturally, friendship in pariahdom excludes Steven, whose skin color and ancestry tie him up with the world of white supremacy and white privilege. And thus the friendship between the black and the white man comes to an end and its ending is as radical as its inception.

After a violent and wild party full of liquor and loud music, the party that is the last accord in "Niggerati Manor's" fall, Steven suddenly leaves the house, not without prior striking two women competing for his amorous attention. The farewell letter he sends to Raymond describes his eugenically-framed anxieties and confirms the impossibility of an effective escape from the racist and eugenically-shaped outside world:

I'm fed up with Harlem and Negroes. You say there is nothing in this race business. In the past I have agreed. Now I wonder. Dubiety surges through me and tantalizes my mind. I have no prejudice, you know; yet recently my being has been permeated with a vague disquiet. ... I shudderand this will astound you-if I have to shake hands with a Negro. I have lived recently in a suddenly precipitated fear that I had become unclean because of my association. So complex and far-reaching has this fear become that I rushed in a panic to a doctor recently to be examined. I feared, unreasonably, and with no definite evidence, that Aline and Janet were unclean and that I had become contaminated. (119)

The letter is so full of eugenic phrasing that one can hardly believe that it is penned by the same man who a couple of months earlier proudly announced his indifference to "American prejudice" of racialism and racism. We thus have figures of contamination and the fear of becoming unclean as a result of Steven's maintaining sexual relations with Aline-anxieties endemic to the discourse of racial purity and degeneration so forcefully rejected at the novel's beginning. Steven's reliance on a doctor in order to assuage his racial panic also bears the imprint of eugenics. One of the reasons for the popularity of eugenics with the medical profession was its cult of the expert and of the scientist. By providing the grounds to treat a physician as the final authority in one's life, the science of heredity assured an even higher position of physicians in US society. Thus, by falling back on eugenic authorities and eugenic treatises at the time, Steven turns into a model Nordic, orienting the world according to the compass of racial essentialism and white supremacy. Not only did his experience of mingling with African Americans not provide a buffer to the encroachment of the hegemonic white Anglo-Saxon world, but it served to construct Steven's world in keeping with eugenic theories. When Steven leaves for 'the world', he does so as a white cultural segregationist, who declares his affinity with “one of Gertrude Stein's lost generation ... or rather post-generation" and decides to become a "Humanist just because they are interested in establishing boundary lines” (136). Raymond is no longer Steven's friend, someone who welcomed Steven's power to be his philosophical mentor and 
"heteros autos" challenging his selfhood within him. He is now Steven's opponent, separated from him biologically and culturally by the color line.

The book's sense of failure grounded in the thwarted friendship and, by proxy, in a failed project of establishing a new life philosophy that would pose a viable alternative to the eugenic jargon of racial absolutism, spilled onto both the book's ending and Thurman's life. The novel ends on a catastrophic note with the suicide of Paul Arbian-a bisexual friend of Steven and Raymond-after he moved out of "Niggerati Manor." His staged death "in crimson mandarin robe" (174) speaks in equal measure of the obsessive fear of the failure of the artistic promise of the Harlem Renaissance, concomitant with "the promise of [Thurman's] own leading role in it” (Van Notten 170-211, 246), as well as suggests tragic consequences to the insoluble racial and sexual dilemmas of the inhabitants of "Niggerati Manor." This sense of doom also accompanied Thurman after the publication of his book. In his correspondence with friends, the writer himself voiced disappointment with the novel, calling it "the most disappointing novel" and "sheer chaos" (Van Notten 249). Ellen Van Notten even speculates that it is possible that Thurman delayed publication of the novel by two years, so unsure was he of its quality. Even in the eyes of its author, the novel that was to pose a radical challenge to the eugenic discourse of degeneration, racial absolutism and racial unknowability and toyed with the idea of cosmopolitan friendship, failed to meet its goal. The conclusion seems to be dreary: in the eugenic times of false politics, interracial cosmopolitan friendships cannot develop and, even if initiated, are doomed to a dismal end. One's good will and trust in the power of philosophical individualism are too weak to override the political and material forces which divide people across races and promote tribal affiliations along "blood lines."

Thurman's pessimism, nevertheless, may be countered by those who subscribe to belief in an interracial cosmopolitan friendship of a different brand-one that does not escape the world, but throws itself into it, combating it on the world's own terms. Such is the case with Arendt who, despite her personal experience of suffering persecution after the Nazi ascension to power in 1933 and her flight from her mother country, still refused to doubt friendship and its power to "make the world a little bit human" (31). Commenting on the possibility of friendship between a German and a Jew in Nazi Germany, Arendt asserted:

Thus in the case of friendship between and a German and a Jew under the condition of the Third Reich it would scarcely have been a sign of humanness for the friends to have said: Are we not both human beings? It would have been mere evasion of reality and of the world common to both at that time; they would not have been resisting the world as it was. A law that prohibited the intercourse of Jews and Germans could be evaded but could not be defied by the people who denied the reality of this distinction. In keeping with a humanness that had not lost the solid ground of reality, a humanness in the midst of the reality of persecution, they would have had to say to each other: A German and a Jew, and friends. But wherever such a friendship succeeded at that time ... and was maintained in purity, that is to say without false guilt complexes on one side 
and false complexes of superiority on the other, a bit of humanness in a world become inhuman had been achieved. (31)

The premises on which Arendt builds cosmopolitan friendship seem initially very much like those of Thurman. Just like him, she challenges the Enlightenment ideal of fraternity and universal humanism, thus anticipating contemporary cosmopolitan critiques. She lays bare the naiveté of the universal language of brotherhood in times of oppression, and its tacit complicity in the system of injustice. However, unlike Thurman, who stops half way in his project to erase the Enlightenment sentiment, Arendt moves further. If Thurman speculates whether friendship is possible under the condition of withdrawal from the world along with an erasure of the presence of the material world and its markers of differences, Arendt has no doubt as to its doomed character and suggests an alternative. To her, friendship in Dark Times of false politics is possible not when one erases the differences imposed by the world, but paradoxically faces them head on. By bringing them to the surface, one does not accept their validity or succumb to their power, but recognizes the role they play in the material world. Thus friendship above divisions is imagined only when one acknowledges the political reality of the same divisions. And then, when forged, it forms the basis for a common "humanness in the midst of persecution" (Arendt 31). Steve and Ray could have said: A Negro and a Nordic, and friends. Cosmopolitan friendship is imaginable even in Dark Times.

\section{Works Cited}

Agamben, Giorgio. “On Friendship.” Contretemps, vol. 5, Dec. 2004, pp. 2-7.

Arendt, Hannah. Men in Dark Times. Penguin Books, 1975.

Bernard, Emily. "Unlike Many Others: Exceptional White Characters in Harlem Renaissance Fiction." Modernism / Modernity, vol. 12, no. 3, 2005, pp. 407-423.

Braidotti, Rossi, et. al., editors. After Cosmopolitanism. Routledge, 2013.

Childs, Donald J. Modernism and Eugenics: Woolf, Eliot, Yeats, and the Culture of Degeneration. Cambridge UP, 2001.

Cuddy, Lois A., and Claire Roche. Evolution and Eugenics in American Literature and Culture, 1880-1940. Essays on Ideological Conflict and Complicity. Bucknell P, 2003.

Currell, Susan, and Christina Codgell. Popular Eugenics: National Efficiency and American Mass Culture in the 1930s. Ohio UP, 2006.

Darrow, Clarence. “The Eugenics Cult.” The American Mercury, June 1926, pp. 129-132.

Davenport, Charles A. "State Laws Limiting Marriage Selection in the Light of Eugenics." Eugenics Record Office Bulletin, vol. 9, Cold Spring Harbor Laboratory, 1913.

Du Bois, W.E.B. “Americanization.” Crisis, vol. 24, no. 4, Aug. 1922, p. 154.

--.. "Miscegenation." Interracialism: Black-White Intermarriage in American History, Literature, and Law, edited by Werner Sollors, Oxford UP, 2000, pp. 461-473.

Darrow, Clarence. “The Eugenics Cult.” The American Mercury, June 1926, pp. 129-132

English, Daylanne K. Unnatural Selections: Eugenics in American Modernism and the Harlem Renaissance. U of North Carolina P, 2004. 
Ganter, Granville. "Decadence, Sexuality, and the Bohemian Vision of Wallace Thurman." Melus, vol. 28, no. 2, Summer 2003, pp. 83-104.

Gilroy, Paul. Against Race: Imagining Political Culture beyond the Color Line. Harvard UP, 2000. Hoyrd, André. "Racialists and Aristocrats: George S. Schuyler's Black No More and Nordicism." African American Humor, Irony and Satire: Ishmael Reed, Satirically Speaking, edited by Dana A. Williams, Cambridge Scholars Publishing, 2007, pp. 16-35.

Hughes, Langston. "The Negro Artist and the Racial Mountain." African American Literary Theory, edited by Winston Napier, New York UP, 2000, pp. 27-30.

Hunter, George William. A Civic Biology Presented in Problems. American Book Company, 1914.

Kline, Wendy. Building a Better Race: Gender, Sexuality, and Eugenics from the Turn of the Century to the Baby Boom. U of California P, 2005.

Knadler, Stephen P. "Sweetback Style: Wallace Thurman and a Queer Harlem Renaissance." MFS Modern Fiction Studies, vol. 48, no. 4, Winter 2002, pp. 899-936.

Kuhl, Stefan. The Nazi Connection: Eugenics, American Racism, and German National Socialism. Oxford UP, 1994.

Larson, Edward J. Summer for the Gods: The Scopes Trial and America's Continuing Debate over Science and Religion. Basic Books, 2006.

Lombroso, Cesare. Criminal Man. Translated by M. Gibson and N. H. Rafter, Duke UP, 2006.

Luczak, Ewa Barbara. Breeding and Eugenics in the American Literary Imagination: Heredity Rules in the Twentieth Century. Palgrave Macmillan, 2015.

Michaels, Walter Benn. Our America: Nativism, Modernism, and Pluralism. Duke UP, 1995.

Nies, Betsy L. Eugenic Fantasies: Racial Ideology in the Literature and Popular Culture of the 1920 s. Routledge, 2002.

Nordau, Max Simon, Degeneration. Translated by G. Work, U of Nebraska P, 1993.

Ordover, Nancy. American Eugenics: Race, Queer Anatomy, and the Science of Nationalism. U of Minnesota P, 2003.

Pinkerton, Steve. "The New Negro" vs. "Nigerati”: Defining and Defiling the Black Messiah." Modernism / Modernity, vol. 20, no. 3, 2013, pp. 539-555.

Pochmara, Anna. The Making of a New Negro: Black Authorship, Masculinity, and Sexuality in the Harlem Renaissance. Amsterdam UP, 2011.

Popple, Naomi. "Imagining Freedom in a Post-Emancipation "Pigmentocracy": Wallace Thurman, Toni Morrison, and Tupac Shakur.” Journal of Black Studies, vol. 46, no. 4, 2015, pp. 404-414. os

Posnock, Ross. Color and Culture: Black Writers and the Making of the Modern Intellectual. Harvard UP, 1998.

Rampersad, Arnold. “Mencken, Race, and America," Menckenia, vol. 115, 1990, pp. 1-11.

Rorty, Richard. Contingency, Irony, and Solidarity. Cambridge UP, 1989.

Ross, Albert. “Menace of Migrating Menace." Century, vol. 102, May 1921, pp. 131-135.

Roosevelt Theodore. Preface. Booker T. Washington, by Emmett J. Scott and Lyman Beecher Stowe, Garden City, 1916.

Rottenberg, Catherine. "Wallace Thurman's The Blacker the Berry and the Question of the Emancipatory City." Mosaic: A Journal for Interdisciplinary Study of Literature, vol. 46, no. 4, Dec. 2013, pp. 59-74.

Said, Edward. "Reflections on Exile." Reflections on Exile and Other Essays. Harvard UP, 2002, pp. 137-149.

Schalk, Sami. “Transing: Resistance to Eugenic Ideology in Nella Larsen's Passing." Journal of Modern Literature, vol. 38, no. 3, Spring 2015, pp. 148-161.

Schuyler, George. "The Negro Art-Hokum.” African American Literary Theory, edited by Winston Napier, New York UP, 2000, pp. 24-26. 
Scruggs, Charles. Sage in Harlem: H.L. Mencken and the Black Writers of the 1920s. The Johns Hopkins UP, 1984.

Singh Amritjit, and Daniel M. Scott III., editors. The Collected Writings of Wallace Thurman. Rutgers UP, 2003.

Stern, Alexandra. Eugenic Nation: Faults and Frontiers of Better Breeding in Modern America. $\mathrm{U}$ of California P, 2005.

Talalay, Kathryn. Composition in Black and White. The Life of Philippa Schuyler. Oxford UP, 1995.

Thurman, Wallace. Infants of the Spring. 1932. Dover Publication, 2013.

Turda, Marius. Modernism and Eugenics. Palgrave Macmillan, 2010.

Turda, Marius, and Paul J. Weindling, editors. "Blood and Homeland": Eugenics and Racial Nationalism in Central and Southeast Europe, 1900-1940.” Central European UP, 2007.

Van Notten, Ellen. Wallace Thurman's Harlem Renaissance. Rodopi, 1994.

Weiss-Wendt, Anton, and Rory Yeomans, editors. Racial Science in Hitler's New Europe, 1938-1945. U of Nebraska P, 2013.

Werbner, Pnina. "Stuart Hall in Conversation with Pnina Werbner." Anthropology and the New Cosmopolitanism: Rooted, Feminist and Vernacular Perspectives, edited by Pnina Werbner, Berg, 2008, pp. 345-365.

Wiggam Albert Edward. The Fruit of the Family Tree. London, 1911. 